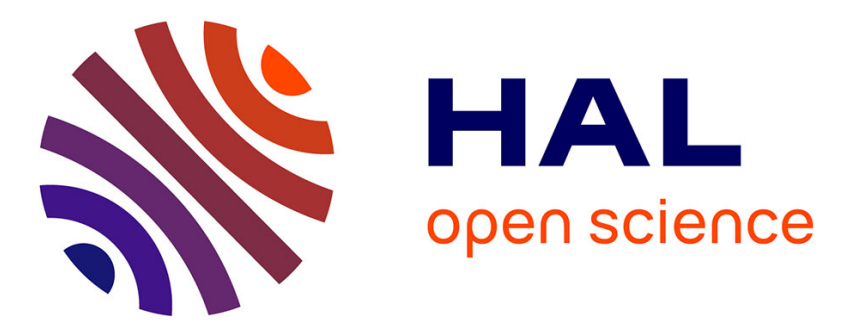

\title{
Plasma prolactin level during transfer of rainbow trout (Salmo gardneri) and atlantic Salmon (salmo salar) from fresh water to sea water Patrick Prunet, Gilles Boeuf
}

\section{To cite this version:}

Patrick Prunet, Gilles Boeuf. Plasma prolactin level during transfer of rainbow trout (Salmo gardneri) and atlantic Salmon (salmo salar) from fresh water to sea water. Aquaculture, 1985, 45, pp.167-176. 10.1016/0044-8486(85)90267-4 . hal-02728721

\section{HAL Id: hal-02728721 \\ https://hal.inrae.fr/hal-02728721}

Submitted on 2 Jun 2020

HAL is a multi-disciplinary open access archive for the deposit and dissemination of scientific research documents, whether they are published or not. The documents may come from teaching and research institutions in France or abroad, or from public or private research centers.
L'archive ouverte pluridisciplinaire HAL, est destinée au dépôt et à la diffusion de documents scientifiques de niveau recherche, publiés ou non, émanant des établissements d'enseignement et de recherche français ou étrangers, des laboratoires publics ou privés.

\section{다(1)(2)}

Distributed under a Creative Commons Attribution - ShareAlikel 4.0 International 


\title{
PLASMA PROLACTIN LEVEL DURING TRANSFER OF RAINBOW TROUT (SALMO GAIRDNERI) AND ATLANTIC SALMON (SALMO SALAR) FROM FRESH WATER TO SEA WATER
}

\author{
P. PRUNET and G. BOEUF' \\ Laboratoire de Physiologie des Poissons/INRA, Campus de Beaulieu, 35042 Rennes \\ Cedex (France) \\ ${ }^{1}$ IFREMER/Centre Océanologique de Bretagne, B.P. 337, 29273 Brest Cedex (France)
}

\begin{abstract}
Prunet, P. and Boeuf, G., 1985. Plasma prolactin level during transfer of rainbow trout (Salmo gairdneri) and Atlantic salmon (Salmo salar) from fresh water to sea water. Aquaculture, 45: 167-176.
\end{abstract}

Hypoosmoregulatory activity of two salmonid species (one smoltifying and one non-smoltifying) was studied by direct transfer of these fish into sea water. Two plasma parameters were followed during the experiments: osmotic pressure and sodium level. Using an homologous radioimmunoassay for salmon prolactin, the plasma level of this hormone was also measured.

Seawater adaptation of rainbow trout appeared to be difficult, as shown by the high increase of osmotic pressure and sodium level. However, after 2 weeks the fish were able to regulate their hydromineral balance. Prolactin level dropped within $24 \mathrm{~h}$ after transfer and remained significantly lower than in the freshwater fish during the experiment. In contrast, Atlantic salmon smolts transferred to sea water were able to control their hydromineral balance within a few days after transfer, as shown by plasma osmotic pressure and sodium level. Moreover, prolactin level was not significantly different between freshwater and seawater fish from day 4 to the end of the experiment. Thus, by measuring plasma prolactin level, it was possible to confirm the two patterns of seawater adaptation presented by Atlantic salmon smolt and rainbow trout. These results are discussed in terms of a possible role of prolactin in salmonid osmoregulation.

\section{INTRODUCTION}

The development of salmonid seawater aquaculture in France has revealed the potential and the limits of such culture systems and has led to a new interest in the physiology of osmoregulation (Boeuf and Harache, 1982). The ability of these fishes to adapt to sea water varies depending on whether we are dealing with smoltifying or non-smoltifying species. Numerous studies have demonstrated that seawater survival of salmon is maximum when fishes are transferred during smoltification (see review by Hoar, 1976; Folmar and Dickhoff, 1980; Wedemeyer et al., 1980). For non-smoltifying species 
such as rainbow trout, seawater adaptation seems to be more difficult, and the development of salinity tolerance is related to body size, large fish adapting more easily than smaller ones (Houston, 1961; Conte and Wagner, 1965; Lahlou et al., 1975; Bath and Eddy, 1979; Jackson, 1981; Johnston et al., 1983; Boeuf and Harache, 1984).

There has been considerable research on the endocrine control of the development of seawater tolerance in salmonids during the last few years; much attention has been paid to thyroid hormones which appear to play a major role in salmon smoltification (Folmar and Dickhoff, 1981; Dickhoff et al., 1982; Grau et al., 1982; Lindahl et al., 1983; Boeuf and Prunet, 1985). Pituitary hormones like prolactin and growth hormone also appear to be important in seawater adaptation (Komourdjian et al., 1976; Nagahama et al., 1977; Bern, 1978; Nishioka et al., 1982). However, the absence of homologous radioimmunoassays of the pituitary hormones has limited the investigation of their role in smóltification and osmoregulation in salm. onids.

Recently, highly purified salmon prolactin has been obtained (Kawauchi et al., 1983; Prunet and Houdebine, 1984) and a homologous radioimmunoassay of salmonid prolactin has been developed and validated (Hirano et al., 1985; Prunet et al., 1985). Using this technique the aim of this study was to measure plasma prolactin levels in salmonids transferred from fresh water to sea water. This study was performed with one smoltifying species, Atlantic salmon (Salmo salar), and one non-smoltifying species, domesticated rainbow trout (Salmo gairdneri).

\section{MATERIALS AND METHODS}

\section{Transfer experiment}

Domesticated rainbow trout (Salmo gairdneri) used in this study were provided by a private hatchery and origined from Brittany. These fishes were 9 months old and their mean weight and length were respectively $245 \pm 2.2 \mathrm{~g}$ and $196.6 \pm 3.5 \mathrm{~mm}$. The rainbow trout were transferred to sea water on 21 November 1983. During the experiment the temperature showed a slow decrease (fresh water, $11^{\circ} \mathrm{C}$ to $9^{\circ} \mathrm{C}$; sea water, $12^{\circ} \mathrm{C}$ to $9^{\circ} \mathrm{C}$ ) and the salinity was fairly constant $(35 \pm 0.5 \%)$. The Atlantic salmon (Salmo salar) were reared in an experimental hatchery in Le Conquet (Brittany). Eggs were imported from Norway. At the date of transfer (12 April 1984) the smolts were 15 months old and had a mean length of $175.8 \pm$ $2.2 \mathrm{~mm}$. The temperature and salinity during the experiment were fairly stable (fresh water, $9-11^{\circ} \mathrm{C}$; sea water, $10-13^{\circ} \mathrm{C}$ and $35 \pm 0.5 \%$ ). For the two experiments the protocol of transfer was the same: one week before transfer the fish were put into $2 \times 2 \mathrm{~m}$ Ewos tanks in running water. Two days before transfer, feeding was stopped with the exception of the control group of Atlantic salmon smolts kept in fresh water, which were fed as 
usual. Smolts in sea water accepted food the day after transfer. On the day of transfer until the end of the experiment rainbow trout kept in fresh water were given food, but trout in sea water accepted food only on day 4 .

Direct transfer to sea water was achieved by turning off the fresh water supply of the tank and by turning on the sea water supply. In that way, the transfer was effected within $2 \mathrm{~h}$ without handling stress. Temperature and photoperiod were natural during the experiment.

\section{Plasma collection}

Blood was collected from the posterior aorta with a heparinized syringe between 2 and 3 p.m. each day. After the fish were weighed and measured, the blood was centrifuged and the plasma frozen at $-20^{\circ} \mathrm{C}$ in aliquots.

\section{Measurements}

Plasma osmotic pressure was measured with a Roebling osmometer $(\mathrm{mOsm} / \mathrm{l})$ and sodium levels with a specific electrode Beckman analizer $(\mathrm{mEq} / \mathrm{l})$. Gill $\mathrm{Na}^{+}-\mathrm{K}^{+}$-ATPase activities were measured according to the method described by Lasserre et al. (1978). Plasma prolactin levels were determined using a homologous radioimmunoassay following the technique described and validated by Hirano et al. (1985) and Prunet et al. (1985).

\section{RESULTS}

\section{Rainbow trout}

Plasma osmotic pressure and $\mathrm{Na}^{+}$concentration after direct transfer to sea water are shown in Fig. $1 \mathrm{~A}$ and $1 \mathrm{~B}$. Initially, there was a large increase in these parameters 1 day after transfer, but the fish began to regulate their hydromineral balance within 7 days and reached the seawater values within 2 weeks. The control group showed no modification of osmotic pressure and $\mathrm{Na}^{+}$concentration.

Plasma prolactin levels decreased rapidly after transfer to sea water. A lower level, which remained stable during the experiment, was reached within 2 days (Fig. 2). The control group kept in fresh water showed a significantly higher plasma prolactin level than the transferred group (Fig. 2). Initially, there was a slight decrease in prolactin levels in the freshwater group, but these levels stabilized after 1 week.

\section{Atlantic salmon}

In order to insure that fully smoltified fish were used in this experiment, gill $\mathrm{Na}^{+}-\mathrm{K}^{+}$-ATPase levels were followed during the smoltification of our population (Boeuf and Prunet, 1985). This criterion, in conjunction with 


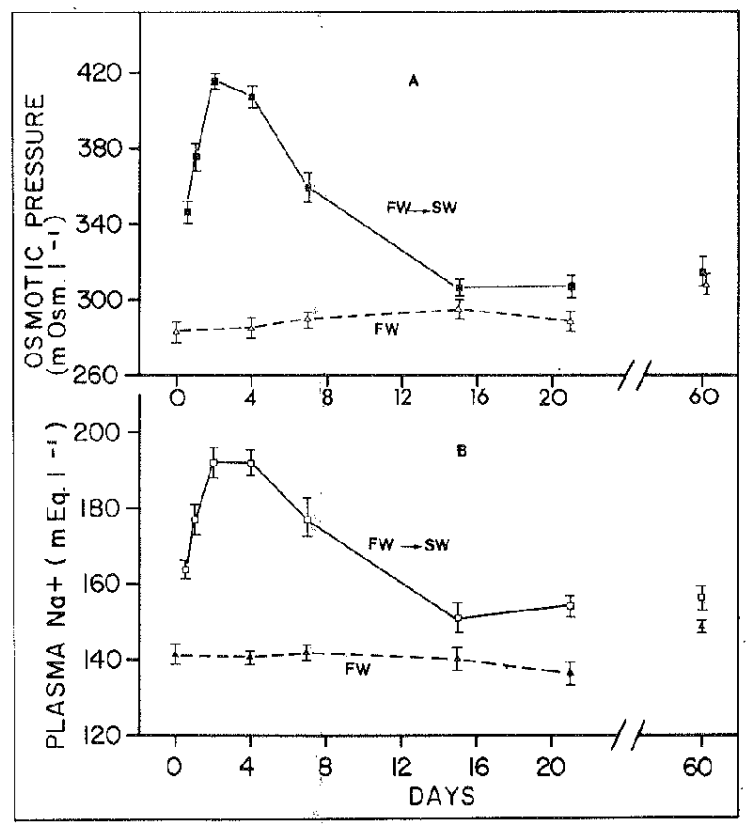

Fig. 1. Transfer of rainbow trout to sea water: (A) plasma osmotic pressure, (B) plasma sodium level.

Each point represents the mean value $\pm \operatorname{SEM}(n=10)$. Dotted line corresponds to the control group kept in fresh water and solid line to the group transferred to sea water.

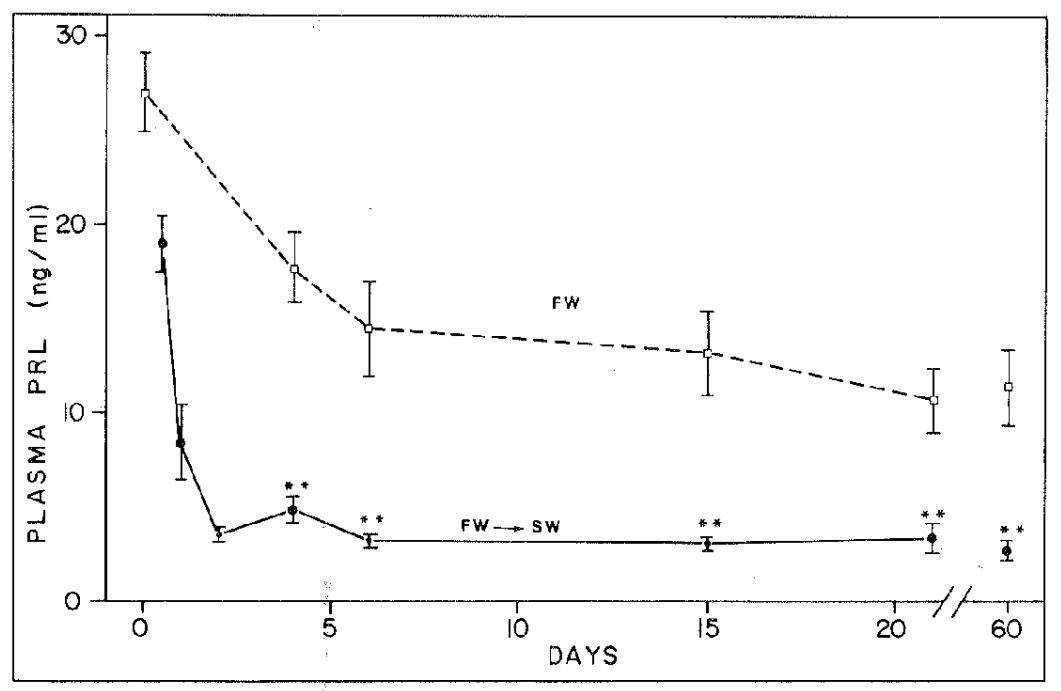

Fig. 2. Change in plasma prolactin (PRL) level in rainbow trout transferred to sea water. Further legend as in Fig. 1.

**: significantly $(P<0.01)$ different from the freshwater control group on the same day (data analyzed using Student's test). 
measurement of the length of the fish has been demonstrated to provide a good method of identification of the smolt population in our natural conditions (Boeuf and Prunet, 1985). Based on this information, the date chosen for transfer of the smolts was 12 April 1984. Gill $\mathrm{Na}^{+}-\mathrm{K}^{+}$-ATPase was at its highest level in a representative sample of our population just before transfer $\left(21.6 \pm 1.3 \mu \mathrm{m} \mathrm{Pi} \cdot \mathrm{mg}_{\text {protein }}{ }^{-1} \cdot \mathrm{h}^{-1} ; n=10\right)$.

Twenty-four hours after transfer, there was an increase in plasma osmotic pressure and $\mathrm{Na}^{+}$concentration (Fig. 3A and 3B). However, the smolts appeared to control their hydromineral balance efficiently and quickly. By the fourth day, these two parameters had decreased to the level of the control group kept in fresh water, and they remained stable during the rest of the experiment. Measurement of plasma prolactin levels in the trans-

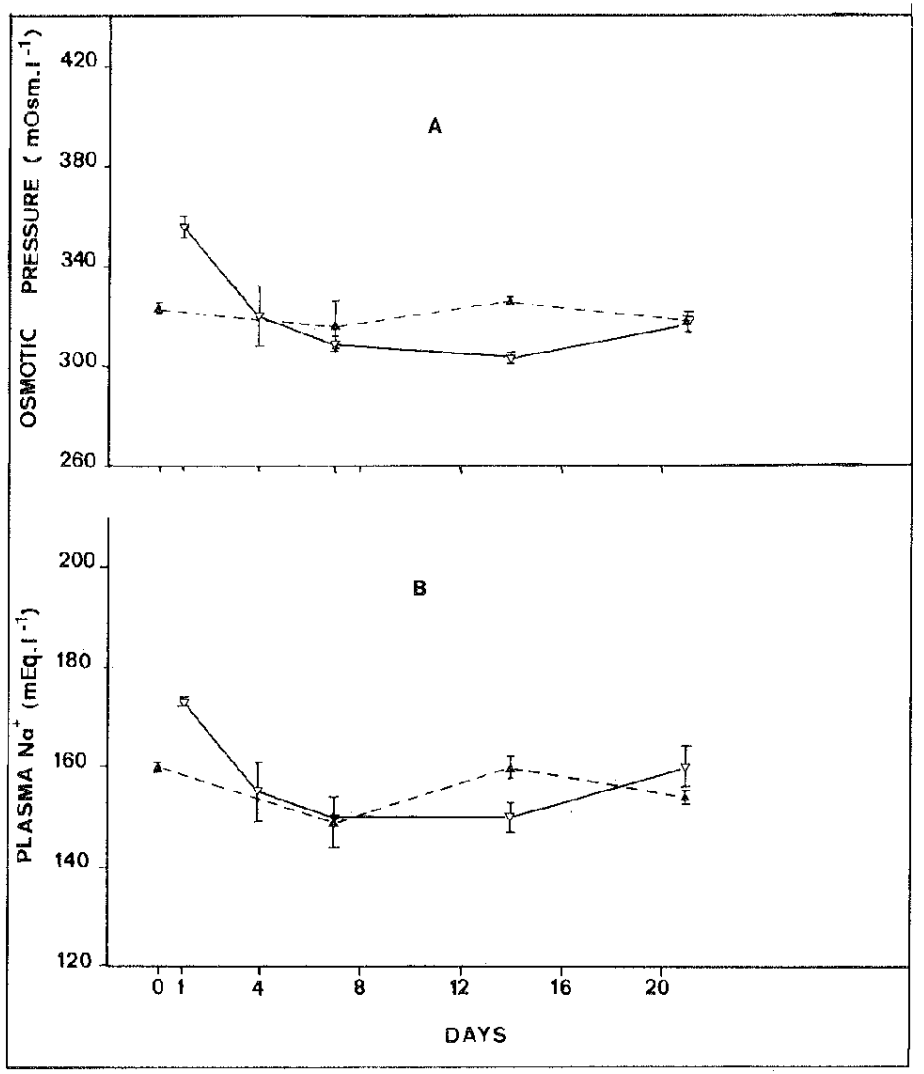

Fig. 3. Transfer of Atlantic salmon to sea water: (A) plasma osmotic pressure, (B) plasma sodium level,

Vertical bars represent the standard error of the mean $(n=5$ for seawater groups and $n=$ 7 for freshwater groups). 
ferred group showed an initial increase $24 \mathrm{~h}$ after transfer followed by a sharp decrease (Fig. 4). From day 7 until the end of the experiment there were no significant differences between the control group kept in fresh water and the transferred group (Fig. 4).

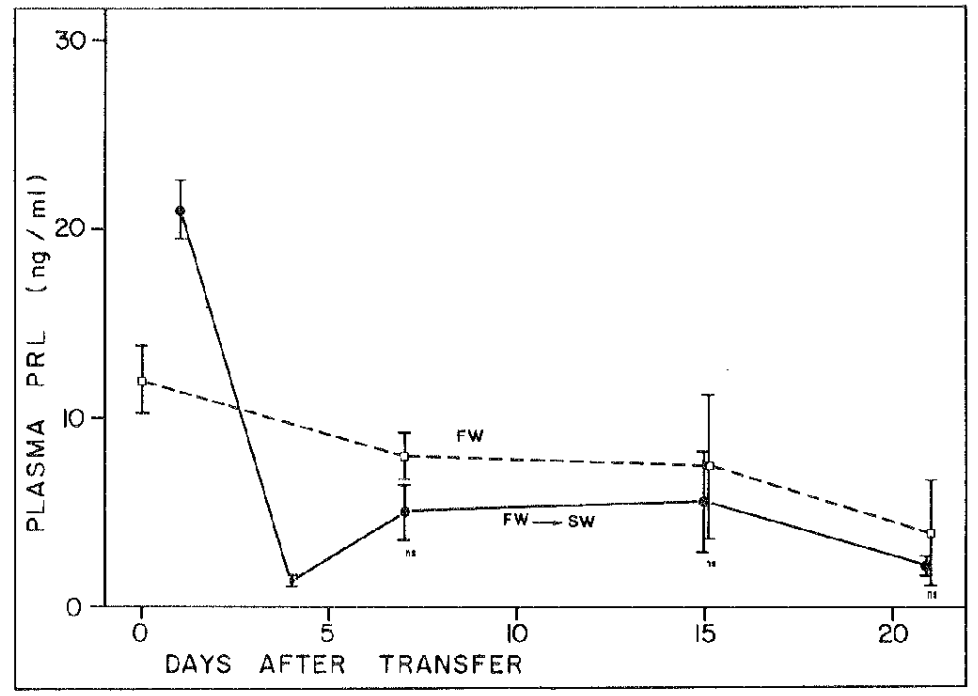

Fig. 4. Change in plasma prolactin (PRL) level in Atlantic salmon after transfer to sea water.

ns: not significantly $(P=0.05)$ different from the freshwater control group (data analyzed using Student's test).

\section{DISCUSSION}

In these transfer experiments on two different salmonid species, Atlantic salmon and rainbow trout, each species presents a characteristic pattern of seawater adaptation. Numerous studies have shown that seawater tolerance develops in salmon during the parr-smolt transformation (Parry, 1960; Conte et al., 1966; Wagner et al., 1969; Knutsson and Grav, 1976; Hoar, 1976) which means that smolts transferred directly to full sea water show a rapid regulation of their "milieu intérieur" (Boeuf et al., 1978; Boeuf and Harache, 1982). A high level of $\mathrm{Na}^{+}-\mathrm{K}^{+}$-ATPase activity in salmonids has been demonstrated to be a good criterion for seawater adaptation in our natural conditions (Lasserre et al., 1978; Boeuf and Harache, 1982).

In contrast, in rainbow trout, a non-smoltifying species, the adaptation to sea water appears to be more difficult. Jackson (1981) reported successful seawater transfer of $30 \mathrm{~g}$ rainbow trout when the salinity did not exceed $30 \%$. However, Lahlou et al. (1975) and Boeuf and Harache $(1982,1984)$ obtained good survival of trout larger than $150 \mathrm{~g}$ in full sea water $(35 \% 0)$. In all cases the fish encountered difficulties in controlling their hydromineral balance, with a long period of osmotic adjustment following trans- 
fer. Until now, the only predictive criterion for seawater adaptation of non-smolting species such as trout appears to be the weight of the fish (Boeuf and Harache, 1982).

The differences in seawater adaptation between Atlantic salmon and rainbow trout appear clearly in our experiments: after direct transfer to sea water rainbow trout needed 2 weeks to adapt to high salinity whereas Atlantic salmon were able to control their hydromineral balance within 4 days. Moreover, $24 \mathrm{~h}$ after transfer, rainbow trout had to face a much higher plasma osmotic pressure and sodium level than Atlantic salmon smolt.

There has been an accumulation of information concerning the involvement of prolactin in fish osmoregulation (see Hirano and Mayer-Gostan, 1978; Clarke and Bern, 1980; Loretz and Bern, 1982). Recently, Hirano et al. (1985) and Prunet et al. (1985) have reported results using a homologous radioimmunoassay for salmon prolactin which support the role of this hormone in freshwater adaptation. As shown in Prunet et al. (1985) and in Figs. 1 and 2, an increase of osmotic pressure in rainbow trout transferred to sea water is associated with a drop of plasma prolactin level within 1 day. The initial slow decrease of prolactin level in the control group kept in fresh water is difficult to explain. However, one can notice that these fishes were not fed on the last 2 days before the transfer but were fed again from the day of transfer until the end of the experiment.

In Atlantic salmon smolt, the results obtained were somewhat ambiguous: $24 \mathrm{~h}$ after transfer there was an increase of osmotic pressure associated with an increase of plasma prolactin level. Such an increase is difficult to explain, although it is also possible in this case to suggest an effect of starvation, as feeding in this group was stopped 3 days prior to transfer. If we compare the results obtained in rainbow trout and Atlantic salmon smolt during the first days after transfer, it appears that smolt do not show the correspondence between plasma osmotic pressure and prolactin level (i.e., high osmotic pressure associated with low level of prolactin). From day 4 onwards, plasma prolactin levels were the same in the transferred group and in control fish kept in sea water. Several authors have shown a greater activity of prolactin cells in smolts kept in fresh water compared to those transferred to sea water (Leatherland and McKeown, 1974; Clarke and Nagahama, 1977; Nagahama et al., 1977). However, these transfer experiments, using Pacific salmon species, were performed at another time of the year (between October and February): as smoltification is a seasonal phenomenon it is possible that we are dealing with differences in fish physiology. Moreover, a correlation between the activity of pituitary cells and the plasma hormone level is not always easy to establish.

It is interesting to note that, associated with this same prolactin level, osmotic pressure and sodium level are also the same in transferred and in freshwater smolts. Such results were also noted by Houston and Threadgold (1963) who reported a higher level of plasma chloride during smoltification compared to the level found in parr. 
In this study, we have shown that the two patterns of control of hydromineral balance after transfer to sea water are associated with two patterns of plasma prolactin variations. From that point of view, Atlantic salmon smolt seems to be more a seawater than a freshwater fish at the end of the smoltification period. However, from this study, it is difficult to draw conclusions on the role of prolactin in the control of osmoregulation, especially when we are considering the results obtained with Atlantic salmon smolt. More information is needed to clarify the involvement of prolactin in the control of salmonid smoltification and also its importance in shortterm adaptation to sea water.

\section{ACKNOWEEDGEMENTS}

We wish to thank Dr. D.S. MacKenzie for his suggestions during the writing of this paper. We gratefully acknowledge the technical assistance of M. Ollitrault and A. Le Roux, and D. Bouix for efficient aid in typing the manuscript. This study was supported by a CNEXO grant.

\section{REFERENCES}

Bath, R.N. and Eddy, F.B., 1979. Salt and water balance in rainbow trout Salmo gairdneri rapidly transferred from fresh water to sea water. J. Exp. Biol., 83: 193-202.

Bern, H.A,, 1978. Endocrinological studies on normal and abnormal salmon smoltification. In: P.J, Gaillard and H.H. Boer (Editors), Comparative Endocrinology. Elsevier/ North-Holland, Amsterdam, pp. 97-100.

Boeuf, G, and Harache, Y., 1982. Criteria for adaptation of salmonids to high salinity seawater in France. Aquaculture, 28: 163-176.

Boeuf, G. and Harache, Y., 1984. Adaptation osmotique à l'eau de mer de différentes espèces (Salmo trutta, Salmo gairdneri, Salvelinus fontinalis) et hybride (Salmo trutta $q \times$ Salvenius fontinalis $\delta$ ) de salmonidês. Aquaculture, 40:343-358.

Boeuf, G, and Prunet, P., 1985. Measurements of gill $\left(\mathrm{Na}^{+}-\mathrm{K}^{+}\right)$-ATPase activity and plasma thyroid hormones during smoltification in Atlantic salmon (Salmo salar L.). Aquaculture, $45: 111-119$.

Boeuf, G., Lasserre, P. and Harache, Y., 1978. Osmotic adaptation of Oncorhynchus

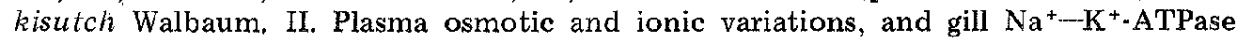
activity of yearling coho salmon transferced to sea water. Aquaculture, 15: 35-52.

Clarke, W.C. and Bern, H.A., 1980. Comparative endocrinology of prolactin. Horm. Proteins Peptides, 8: 105-197.

Clarke, W.C. and Nagahama, Y., 1977. Effect of premature transfer to sea water on growth and morphology of the pituitary, thyroid, pancreas, and interrenal in juvenile coho salmon Oncorhynchus kisutch. Can. J. Zool., 55: 1620-1630.

Conte, F.P. and Wagner, H.H., 1965. Development of osmotic and ionic regulation in juvenile steelhead trout. Comp. Biochem. Physiol., 14: 603-620.

Conte, F.P., Wagner, H.H., Fessler, J. and Gnose, C., 1966. Development of osmotic and ionic regulation in juvenile coho salmon Oncorhynchus kisutch. Comp. Biochem. Physiol., 18: 1-15.

Dickhoff, W.W., Folmax, L.C., Mighell, J.L. and Mahnken, C.V.W., 1982. Plasma thyroid hormoties during smoltification of yearling and underyearling coho salmon and yearling chinook salmon and steelhead trout. Aquaculture, 28: 39-48. 
Folmar, L.C. and Dickhoff, W.W., 1980. The parr-smolt transformation (smoltification) and sea-water adaptation in salmonids. A review of selected literature. Aquaculture, $21: 1--37$.

Folmar, L.C. and Dickhoff, W.W., 1981. Evaluation of some physiological parameters as predictive indices of smoltification. Aquaculture, 23:309-324.

Grau, E.G., Specker, J.L., Nishioka, R.S, and Bern, H.H., 1982, Factors determining the occurrence of the surge in thyroid activity in salmon during smoltification. Aquaculture, 28: 49-57.

Hirano, T. and Mayer-Gostan, N., 1978. Endocrine control of osmoregulation in fish. In: P.J. Gaillard and H.H. Boer (Editors), Comparative Endocrinology. Elsevier/North Holland, Amsterdam, pp. 209-212.

Hirano, T., Prunet, P., Kawauchi, H., Tokahashi, A., Kubota, J., Nishioka, R.S., Bern, H.A., Takada, K. and Ishii, S., 1985. Development and validation of a salmon prolactin radioimmunoassay. Gen. Comp. Endocrinol. (in press).

Hoar, W.S., 1976. Smolt transformation: evolution, behavior and physiology. J. Fish. Res. Board Can., 33: 1233-1252.

Houston, A.H., 1961. Influence of size upon the adaptation of steelhead trout, Salmo gairdneri, and chum salmon, Oncorhynchus keta, to sea water. J. Fish. Res. Board Can., 18: 401-415.

Houston, A.H. and Threadgold, L.T., 1963. Body fluid regulation in smolting Atlantic salmon. J. Fish. Res. Board Can., 20: 1355-1369.

Jackson, A.J., 1981. Osmotic regulation in rainbow trout (Salmo gairdneri) following transfer to sea water. Aquaculture, 24: 143-151.

Johnston, C.E., Birt, T.P. and Murphy, J.L., 1983. Branchial sodium-potassium ATPase activity and growth of rainbow trout in sea water. Prog. Fish. Cult, 45:19-23.

Kawauchi, H., Abe, K., Takahashi, A., Hirano, T., Hasegawa, S., Naito, N. and Nakai, Y., 1983. Isolation and properties of chum salmon prolactin. Gen. Comp. Endocrinol., 49: $446-458$

Knutsson, S. and Grav, T., 1976. Sea water adaptation in Atlantic salmon (Salmo salar L.) at different experimental temperatures and photoperiods, Aquaculture, 8: 169187.

Komourdjian, M.P., Saunders, R.L. and Fenwick, J.C., 1976. The effect of porcine somatotropin on growth and survival in sea water of Atlantic salmon, Salmo salar, parr. Can. J. Zool., 54:531-535.

Lahlou, B., Crenesse, D., Bensahla-Talet, A. and Porthe-Nibelle, J., 1975. Adaptation de la truite d'élevage à l'eau de mer. Effets sur les concentrations plasmatiques, les échanges branchiaux et le transport intestinal du sodium. J. Physiol. (Paris), 70: 593-603.

Lasserre, P., Boeuf, G. and Harache, Y., 1978. Osmotic adaptation of Oncorhynchus kisutch Walbaum. I. Seasonal variations of gill $\mathrm{Na}^{+}-\mathrm{K}^{+}$-ATPase activity in coho salmon, $0^{+}$-age and yearling, reared in fresh water. Aquaculture, 14:365-382.

Leatherland, J.F, and McKeown, B.A., 1974. Effect of ambient salinity on prolactin and growth hormone secretion and on hydromineral regulation in kokanee salmon smolts Oncorhynchus nerka. J. Comp. Physiol., 89: 215-226.

Lindahl, K., Lundqvist, H. and Rydevik, M., 1983. Plasma thyroxine levels and thyroid gland histology in Baltic salmon (Salmo salar L, ) during smoltification. Can. J, Zool., 61: $1954-1958$.

Loretz, C.A. and Bern, H.A., 1982. Prolactin and osmoregulation in vertebrates. Neuro endocrinology, 35:292-304.

Nagahama, Y., Clarke, W.C. and Hoar, W.S., 1977. Influence of salinity on ultrastructure of the secretory cells of the adenohypophyseal pars distalis in yearling coho salmon Oncorhynchus kisutch. Can. J. Zool., 55: 183-198. 
Nishioka, R.S., Bern, H.A., Lai, K.V., Nagahama, Y. and Grau, F.G., 1982. Change in the endocrine organs of coho salmon during normal and abnormal smoltification an electron-microscope study. Aquaculture, 28:21-38.

Parry, G., 1960. The development of salinity tolerance in the salmon, Salmo salar L. and some related species. J. Exp. Biol., 37:425-434.

Prunet, P. and Houdebine, L.M., 1984. Purification and biological characterization of chinook salmon prolactin. Gen. Comp. Endocrinol., 53:49-57.

Prunet, P., Boeuf, G. and Houdebine, L.M., 1985. Blood and pituitary prolactin levels in rainbow trout during the adaptation to different salinities. (Submitted for publication.)

Wagner, H.H., Conte, F.P. and Fessler, J.L., 1969. Development of osmotic and ionic regulation in two races of chinook salmon Oncorhynchus tschawytscha. Comp. Biochem. Physiol, 29: 325-341.

Wedemeyer, G., Saunders, R.L. and Clarke, W.C., 1980. Environmental factors affecting smoltification and early marine survival of anadromous salmonids. Mar. Fish. Rev., $42: 1-14$. 